\title{
Reviewing perspectives on third-party impacts of mega-regional trade agreements: implications for Brazil
}

\author{
Revisando perspectivas sobre impactos em terceiros países dos \\ acordos comerciais megarregionais: implicações para o Brasil
}

NIELS SONDERGAARD*,**

RESUMO: O presente artigo-resenha examina o impacto potencial dos acordos comerciais megarregionais no Brasil como um terceiro país. A literatura inicialmente revisada identifica a "regulação profunda" proposta nos acordos mega-regionais como uma expressão de mudanças estruturais no sistema comercial internacional, o que, apesar da presente estagnação dessas negociações, aponta a relevância de escrutinar o seu impacto potencial em países excluídos. $\mathrm{O}$ artigo subsequentemente examina projeções feitas sobre os impactos econômicas de curto e médio prazos deste tipo de acordo comercial no Brasil como um terceiro país, e em seguida engaja-se com perspectivas que tratam as suas implicações estruturais de longo prazo.

PALAVRAS-CHAVE: Acordos megarregionais; Brasil; Cooperação regulatória; Harmonização regulatória; Balança comercial.

ABSTRACT: The present review article examines the potential impact of mega-regional trade agreements on Brazil as a third-party. The literature initially reviewed identifies the "deep regulation" proposed in mega-regional agreements as an expression of structural changes within the global trading system, which in spite of the current stagnation of these negotiations highlights the relevance of scrutinizing their potential implications for outsiders. The article subsequently examines projections made of the short- and intermediate term economic impacts of this type of trade agreement on Brazil as a third-party, and here upon engages with perspectives treating their long-term structural implications.

KEYWORDS: Mega-regional trade agreements; Brazil; Regulatory cooperation; Regulatory harmonization; Trade balance.

JEL Classification: F17.

\footnotetext{
* Doutorando, Instituto de Relações Internacionais, Universidade de Brasília, Brasília - DF, Brasil. E-mail: nielssonder888@gmail.com. Submitted 30/June/2017; Approved: 28/3/2018.

** Bolsista do Conselho de Aperfeiçoamento de Pessoal de Nível Superior (CAPES).
} 


\section{INTRODUCTION}

As the focus of trade negotiations recently has been moving away from the multilateral track, the so called 'mega-regional' agreements have constituted the latest attempts to expand the depth and scope of international commercial regulation. Due to their preferential nature, questions have been raised about how these agreements might impact third-countries. Through scrutiny of recent literature treating the central characteristics and projected implications of these mega-regional dynamics, the present review article examines the position of Brazil as a likely outsider of these commercial trends. Although the two most advanced attempts at establishing mega-regional agreements, the Transatlantic Trade and Investment Partnership (TTIP) and the Trans-Pacific Partnership (TPP) are currently stalled, the present article departs from the premise that they reflect more fundamental changes within the global trading system, with a likelihood of concretizing in largely similar future treaties. Studies conducted to evaluate the potential effects of TTIP, TPP, and other less advanced mega-regionals, on Brazil as a third-party are thereby believed to draw an approximate picture of the ramifications of Brazilian non-participation. In certain instances, projections of possible Brazilian inclusion in such treaties serve as a comparative parameter.

The article departs from a review of authors treating the advent of mega-regionals as the latest wave of the recent changes away from multilateralism and towards preferentialism within the global trading system. Hereupon, literature with focus on the channels through which spillover effects of mega-regionals may affect third-parties is analyzed. This is followed by a review of projections made of the short- and intermediate term economic impacts on Brazil of agreements which so far have been on the table. Finally, contributions which incline towards analyzing the more long-term and structural consequences of mega-regionals on outsiders in general, - and Brazil in particular - are assessed.

The review indicates that systemic shifts within the global economy, with which mega-regionals are related, are bound to impact Brazil, - independently of the country participating or not. Yet, contrary to arguments often advanced in the Brazilian debate, the immediate short-term consequences of standing outside these agreements in terms of welfare effects either appear to be negligible, or even slightly positive. Participation appears to imply detrimental consequences for the country's already pressed manufacturing sector, while simultaneously cementing dependency on exports of raw materials. Because the US and the EU have defined the content of mega-regional proposals so far, Brazil would not have much room to shape their rules in case of participation but would also be forced towards indirect normative adoption in the case of non-participation. Faced with these prospects, the present halt in the formation of mega-regional trade agreements should in fact suit Brazil. 


\section{CRISIS OF THE MULTILATERAL TRADING SYSTEM AND SURGING PREFERENTIALISM}

The slowdown of the multilateral trading system's normative production has been held by different authors as a central factor in spurring alternative venues for the institutionalization of international trade relations. The inconclusiveness of the Doha negotiations is emphasized by Yong as symptomatic of the weakening of the multilateral track, which is explained by circumstances such as the multitude of new WTO members leading to more complex negotiations, post-2008 protectionism, and divisions between developed and developing countries (Yong, 2014). Through Low's characterization, the WTO's capacity to spur negotiation outcomes has gradually been diluted, wherefore the organization has been reduced to management of existing agreements and dispute settlement (Low, 2015, p.16).

The trend towards fragmentation of global trade has become evident as WTO member states increasingly make use of the provision in the Article 24 of the 1994 agreement, which permits the formation of preferential trade agreements between two or more members ${ }^{1}$. Acharya et al. (2011) thus draw attention to a dual movement, comprising of an exponential surge in preferential trade agreements since the early 1990s towards 2010, coupled with a trend from plurilateralism towards bilateralism, meaning that more than $80 \%$ of agreements signed in this period were bilateral. This is referred to as a "changing structural configuration of PTAs" towards bilateralism (p.38), which displays a tendency towards becoming increasingly cross-regional. It thereby constitutes a strategic tool for states to gain market access in distant regions, but also has the effect of fragmenting international trade rules into a myriad of particular statutes pertaining to each specific agreement (Acharya et al., 2011).

The drivers behind the shift away from multilateralism and towards bilateralism from the turn of the millennium have been treated by Wilson (2015). Herein, three root causes for this tendency are presented as; frustration with the multilateral track, the urge of certain states to engage with more WTO Plus issues ${ }^{2}$, as well as a defensive rationale of avoiding trade isolation, as this sort of agreements become increasingly common (Wilson, 2015, p.346). Anuradha also stresses how aversion in relation to exclusion from the quickly growing web of preferential trade agreements (PTAs) motivates many governments to sign these treaties, with less consideration to their long term implications (Anuradha, 2016).

Though some measure of scholarly agreement regarding the general movement

\footnotetext{
${ }^{1}$ Paragraph 1 through 8 of Article 24 permits the formation of customs unions or free-trade areas below a range of provisions related to border trade, refrainment from elevation of tariffs upon non-members, the timeframe for implementation, notification and information disclosure, and the elimination of duties on trade within the free-trade area/custom union.

2 'WTO Plus' issues refers to commitments which are more stringent, and which spans beyond those agreed upon in the original WTO agreement, such as those related to labor, environment, intellectual property rights, public procurement, competition policy, trade facilitation, and rules of origin.
} 
towards PTAs can be ascertained, its broader consequences appear rather more blurred. The fragmentary dynamics within the institutional framework(s) for global commerce have often been viewed with concern within the literature of international trade. Jagdish Bhagwati's (2008) "spaghetti bawl” metaphor has frequently been used to describe the confusing situation brought about by a myriad of overlapping bi- and plurilateral trade relations permeating the global economy. Bhagwati assumes a critical stance towards the proliferation of PTAs, due to their exclusionary nature, and to the complexities and distortions which numerous rules of origin and overlapping regulations entail. The author furthermore highlights the asymmetries implied by PTAs in terms of non-trade related demands, which they may serve to impose particularly on developing nations, on behalf of developed countries (Bhagwati, 2008).

Another pitfall associated with the spread of PTAs, as accentuated by Josling, is that they might tend to grab the low-hanging fruits by concluding agreement on less complicated issues, referring more difficult matters to the WTO, and thus ultimately leaving additional obstacles to solve within this forum (Josling, 2011, p.146). Yet, the recent surge of a myriad intertwined PTAs has, according to Solis and Wilson (2017), provided an incentive to seek more comprehensive arrangements. The context of a fragmented trading system thereby constitutes an explanatory background for the rise of mega-regional trade negotiations as a structural turn towards wider and more uniform commercial institutions (Solis \& Wilson, 2017, p.11-12). In spite of the difficulties of effectively launching the mega-regionals - not least due to a variety of geopolitical concerns involved - such perspectives become interesting in so far as they approximate an explanation of the rise of this new template for trade agreements as a systemic response to the lack of an ordering framework for global trade. This makes it possible to view the attempts at constructing these treaties as part of a structural dynamic which might become manifest through its concretizations in TTIP, TPP, and the Regional Comprehensive Economic Partnership (RCEP), but which cannot be limited to these specific negotiation processes. This may be corroborated by Schwab and Bhatia, who stress that due to the stagnation at the WTO, "mega-regionals and other forms of plurilaterals may be the inevitable direction taken by likeminded countries in a globalized world" (Schwab \& Bhatia, 2014, p.19).

At their presently embryonic state, some debate revolves around whether mega-regionals may be viewed as an essentially novel pillar of the international trading system. Such perceptions appear to be evident in Meléndez-Ortiz' characterizations of mega-regionals as a third constitutive element in the trend of regional integration, alongside cross-regional bilateral FTAs, and consolidative regional trade agreements (RTAs) which merge existing agreements (Meléndez-Ortiz, 2014, p.13). Nakagawa (2016) describes the advent of mega-regionals as the hitherto culmination of a turn towards the incorporation of non-tariff issues within the institutional framework for global commerce. Differently from Meléndez-Ortiz, Nakagawa does not present such agreements as fundamentally new, but rather as vehicles for the intensification of elements already embedded within existing FTAs, which relate to regulatory convergence and cooperation (Nakagawa, 2016). 
Although elements of deep-regulation may be visible in previous agreements, the expression which they assume through mega-regionals seems to be of an unprecedented extent. A range of authors are also inclined to consider the mega-regionals as something uniquely novel, due to the scale of the expansion of their regulatory scope, which constitutes a fundamental re-definition of the "national" normative space. The shift of attention away from tariff barriers, and towards the reduction of domestic trade obstacles and on regulatory hurdles is portrayed by $\mathrm{De}$ Bievre and Poletti as a change towards an essentially different trade agenda (De Bievre \& Poletti, 2016, p.2). Bown (2017) highlights that while RTAs proliferating in the 1990s included non-tariff disciplines, the period after the financial crisis has seen increased demands from businesses in developed countries to reduce certification-related and regulatory costs. Regulatory coherence between standards in the EU and the US has thus come to stand as an absolutely central part of the TTIP negotiations; both due to the goal of reducing divergence of regulation between these two regions, but also with a broader intention of seeing the global dissemination of these norms (Bown, 2017). The new disciplines on the table in these negotiations have been summarized by authors in the area as public procurement, competition policy, transparency measures, investment protection, intellectual property, environmental and labor standards, industrial policies, state-owned enterprises, as well as the harmonization and convergence around technical standards (Bull et al., 2015; Carneiro, 2014; Hamilton \& Blockman 2015).

The TTIP appears to stand as the mega-regional proposal with the strongest degree of permeation of legislative areas normally situated within the scope of national political authority - also making it the object of much negative sentiment which apparently has stalled the further advance of its present configuration. This unprecedented allocation of regulative authority below the TTIP has made Young depict it as highly extensive in terms of both breadth and depth; comprising of a broad arrays of economic and administrative subfields, which become deeply restructured and inserted below the clauses of this accord (Young, 2016). The authors reviewed have thus been inclined towards associating mega-regionals with a dynamic within the global trading system, which implies a rather profound institutionalization of internationally agreed norms and benchmarks at the national level, facilitating deep economic integration between signatories. It follows that due to the scope of the agreements under negotiation, they do not only wield the potential to intensify economic interactions between member states, but also constitute a process which depending on the specific provisions eventually established may impact third-countries significantly.

\section{TRADE DIVERSION AND THIRD-PARTY IMPACTS}

In The Custom Unions Issue (1950), Jacob Viner treated the consequences of preferential trade arrangements. While Viner stressed the potential for trade creation among the member states which such agreements might wield, he similarly 
pointed towards the pitfall of trade diversion which the shift of procurement from a low-cost third-country, toward a high-cost member state might bring about (Viner, 1950). It may thus be argued that an initial evaluation of the impact of megaregional trade agreements on third-countries should aim to assess the likely extend of trade diversion.

Some observers tend to deemphasize the risk of trade diversion in contemporary global commerce. Hoekman (2015) underlines that the fact that relatively few tariff barriers exist between the global economic core regions today, means that the extend of trade diversion due to commercial integration probably also will be limited. Yet, the elimination of tariff peaks in specific sectors may still divert trade from countries excluded from these agreements (Hoekman, 2015, p.68-69). With regards to the TTIP, Gill et al. (2015) also point to the possibility that trade diversion may imply negative effects on outsiders. Yet, as this only concerns goods produced in the EU or the US, the export composition of many developing countries - largely characterized by primary commodities often imported by both the EU and the US - means that trade diversion becomes less likely (Gill et al., 2015, p.7-8). The likeliness of trade diversion due to proliferating PTAs is also questioned by Mavroidis, who accentuates the lack of clear empirical evidence in relation to this question (Mavroidis, 2011).

Some measure of preoccupation can also be detected within the debates regarding the potential for trade diversion resulting from preferential trade arrangements. Though Sorgho (2016) finds that the proliferation of RTAs since 1995 has been positively correlated with increases in global trade, he also detects a significant degree of trade diversion due to the "spaghetti bowl phenomenon". Furthermore, membership of multiple RTAs is found to have a negative effect on the extend of direct trade creation of these agreements. Rather than promoting trade, the high administrative costs due to the superposition of RTAs are found to lead to considerable trade diversion (Sorgho, 2016). This leaves the question of whether the signature of mega-regionals would further exacerbate this problem, or whether their uniformization of standards might help to alleviate the fragmentation of rule systems.

Apart from direct effects in terms of trade creation- and diversion, Freytag et al. (2014) also expose some more indirect, yet potentially significant, implications associated with the establishment of mega-regional agreements. Such indirect effects may concretize as tariff-jumping ${ }^{3}$ or trade deflection ${ }^{4}$, but also through dynamic effects of liberalization. The latter refers to productivity gains of companies inside a free-trade area due to economies of scale and increased capital accumula-

\footnotetext{
${ }^{3}$ Tariff jumping refers to a situation when enterprises from third-countries are pushed to establish direct representation/production inside a free-trade area in order to avoid external barriers.

${ }^{4}$ Depending on rules of origin adopted within a given agreement, trade deflection may become evident as third-country producers ship goods into the area through the participant with the easiest access.
} 
tion, which tends to become evident in a long-term perspective (Freyteg et al., 2014) In a similar vein, Dadush points to the potentially detrimental consequences which such improvement of the competitive position of insider firms might wield on thirdcountry industries (Dadush, 2014). Increased attention towards dynamic effects therefore appears highly important in any preliminary analysis of the global impacts of mega-regional agreements, in spite of the difficulties associated with the estimation of their gradually increasing significance over time.

Notwithstanding the risk of traditional trade diversion associated with the lowering of tariff rates within large FTAs, scholarly discussions regarding megaregionals have mainly revolved around the possible consequences of mutual approximation of regulatory standards. Elliott hints at the dangers of "regulatory trade diversion", as exporters from third-parties - often developing countries - face competitive disadvantages when harmonization results in highly complex standards (Elliott, 2016). Discrimination in NTB reductions, inconsequential reductions, and potentially increased costs of compliance are also highlighted by Francois et al. as central issues which might compromise third-parties standing outside such agreements (Francois et al., 2013). The impact on third-countries of regulatory convergence will likely depend on the particular mechanisms adopted. Options for regulatory convergence are manifold, but some central categories comprise of mutual recognition of standards 5 , harmonization ${ }^{6}$ of standards, and co-ordination ${ }^{7}$ (De Ville, 2016, p.4; Schoeder, 2016, p.495; Young, 2015, p.1256). Yet, a key point in this regard also appears to be related to the question of whether, and to what degree, these preferences are extended to outsiders.

Another body of literature tends to emphasize the potential for positive spillovers on third-parties of regulatory convergence in mega-regional trade agreements. Akman et al., (2015) accentuate that in contrast to tariff preferences, regulatory changes are not inherently discriminatory. As follows, their potential to benefit third-parties depends on the particular shape they are given within the agreement, and of their level of restriction to insiders (Akman et al., 2015). In a similar vein, Aichele and Felbermeyer (2015) stress the importance of the specific rules established for third-countries. Hereunder, it becomes highly relevant whether mutual recognition is made dependent on criteria which also may be open to producers in third-party countries, and whether less restrictive rules of origin are adopted (Aichele \& Felbermeyer, 2015).

\footnotetext{
${ }^{5}$ Mutual recognition of standards refers to the establishment of legal equivalence among a range of standards, so that the recognition in one-member state automatically entails recognition in the others, in spite of the different mechanisms of approval of the states in question.

${ }^{6}$ Harmonization of standards in trade agreements refers to the establishment of common standards and constitutes the deepest level of regulatory convergence.

${ }^{7}$ Co-ordination of standard-setting refers to the mutual monitoring of testing procedures, informationsharing and approximation of standards, without necessarily making them entirely equivalent.
} 
Regulatory harmonization among parties in a trade agreement may, according to a study conducted by Shepherd (2007), serve to increase exports from thirdcountries to this area. This becomes contingent upon whether compliance costs surpass potential profit from simplification and universalization of standards. The study's simulations indicate that even third-countries with high compliance costs may stand to benefit from the general harmonization process (Shepherd, 2007). Menon (2014) also stresses the "public good" character of the harmonization of standards, and the prospects of their eventual multilateralization, through accession by non-members, as a way out of the present fragmentation of the global trading system (Menon, 2014, p.481).

Baldwin (2014a) draws a clear distinction between tariff-related differentiations between insiders and outsiders in traditional trade agreements - characterized as hard preferences - and the regulatory elements of new trade agreements - referred to as soft preferences. In contrast to the exclusionary nature of the former, the latter are of a much more "leaky" character, making them more difficult to reserve for a certain group of member countries. Baldwin sustains that such trends within mega-regional trade agreements are more likely to benefit third-countries, than the hard preferences previously characterizing trade agreements (Baldwin, 2014a).

The increasing internationalization of commodity chains and cross-border investments are also held by Herwig (2016) as important factors which provide an incentive for insiders of trade agreements to avoid excessively high regulatory barriers, to facilitate operations of enterprises active in third-countries. This even makes the author question whether the notion of national regulatory sovereignty is tenable, stressing that international economic interconnection might pose different imperatives to seek a supra-national pooling of regulatory authority (Herwig, 2016, p.268). Though little is known about the third-party impact of the "deep regulation" of mega-regionals, these more optimistic perspectives point to some highly complex impacts, which also makes it difficult to conclude that non-participation, per-se, will wield negative implications.

A somewhat more critical stance towards the potential impact on thirdcountries of the mega-regional agreements has been adopted by other authors within the field. Schmieg (2015) underscores the high degree of empirical uncertainty associated with the TTIP's consequences for developing countries and claims that many assessments tend to be based on overtly optimistic presumptions. A crucial point relates to the adaptive capacity which developing countries possess in order to respond to changes in the regulatory framework within such an extensive freetrade area (Schmieg, 2015). Ulgen also draws attention to the risk of regulatory trade diversion which the TTIP template implies for third-countries with a higher degree of exposure to international market changes (Ulgen, 2014). The same issues are raised by Ciuriak (2014) in relation to the TPP, who indicates that discriminatory NTB reductions and exclusion of service-providing developing countries, such as India, could have very negative impacts. Yet, more inclusive rules of origin and 
investment liberalization are claimed to mitigate some of these consequences (Ciuriak, 2014, p.8).

Chen and Matoo (2008) examine the impact of standards harmonization within a free-trade area on third-parties, according to the GDP and R\&D expenditures of these countries. The authors find a positive correlation to be evident between exports and GDP and R\&D expenditures, respectively. In cases when restrictive rules of origin are adopted within trade agreements, benefits accrue exclusively to members, at the expense of third-parties (Chen \& Matoo, 2008). Thus, while this finding indicates that wealthy third-countries may benefit from harmonization, it also hints at the negative spillovers implied by rigorous rules of origin, and risks of poorer countries not possessing the recourses to adapt to new regulatory norms.

A more pronounced degree of skepticism regarding the alleged beneficial spillover on third-parties is presented by Aggerwal and Evenett (2015). Apart from potential investment diversion away from third-countries and towards FTA members, the authors also list a series of risks of regulatory discrimination, favoring insiders vis-a-vis outsiders in a trade agreement, such as; regulatory exemptions, favorable tests, faster reviews, leniency in punitive measures, broader appeal rights, and targeting of enforcement recourses towards members (p.47). The authors therefore highlight that as the focus of trade negotiations has moved towards behindborder issues, new kinds of discrimination harmful to third-parties could well surge within this space (Aggerwal \& Evenett, 2015).

Such preoccupations may also be supported by Matoo, who finds that while regional regulatory harmonization has the effect of increasing intra-regional trade, as well as exports from third-party developed countries, exports from developing third-party countries decline (Matoo, 2015). On a developing country firm-level, Maskus et al., also find that short-term adaption costs to developed country regulatory harmonization may constitute significant barriers of entry to these markets (Maskus et al., 2005). A revision of different perspectives on the third-party impact of "regulation intensive" PTAs thereby suggests that this element does wield significant ramifications within the broader structures of global commerce. The particular impact though, appears to vary, and to be highly dependent on the adaptive capacity, existing domestic legislation, and sectorial composition of the specific third-country in question.

\section{BRAZIL WITHIN THE GLOBAL TRADE DYNAMICS}

With the structural transformation of the Brazilian economy from the early 1990s, a re-orientation of Brazil's global economic engagement was also sought. The significance of Mercosul as a center-piece for Brazilian international insertion became evident from this point in time. Though he stresses how Mercosul initially should be viewed as part of a neoliberal turn towards opening of the Brazilian economy, Bernal- 
Meza highlights the change in Brasilia's perception of the organization's instrumental purpose over time, as it gradually came to serve as a means to resist the US' attempts to spur region-wide liberalization through ALCA (Bernal-Meza, 2008). At the outset of the $21^{\text {st }}$ century, Brazil dedicated many efforts at multilateral negotiations, which nonetheless became frustrated with the inconclusiveness of the Doha Round. Though a few extra-regional FTAs have been signed between Mercosul and a small handful of countries, the block's present agreements can only be ascribed a very minor economic significance (Mendoza, 2012).

The restrictions posed by the impossibility of negotiating on an individual country basis, due to the common external tariff, have made some observers highlight the danger of commercial isolation in a context of negotiation of mega-regional agreements (Canuto, 2015; Illescas, 2015; Torezani, 2015), and call for a reorientation of Brazilian global economic integration (Braga, 2015; Pereira, 2013; Thorstensen, 2012). This points to the relevance of reviewing the possible consequences of standing outside the process of mega-regional consolidation, through projections which so far have been on the table.

A frequently cited study has been conducted by Thorstensen and Ferraz (2014), who examine the consequences of Brazilian exclusion from the TTIP and TPP, in scenarios implying different degrees of tariff and non-tariff reductions. The authors find that the consequences for Brazil of a successful conclusion of the TTIP would amount to a $0,6 \%$ drop in exports to this area, in the case of the complete elimination of tariff barriers, and a $5 \%$ drop in a scenario with complete tariff extinction and a $50 \%$ NTB reduction. The export losses in each of these scenarios amount to US\$ 0,4 billion and US\$ 3,8 billion, respectively. With regards to the third-party impact on Brazil of a successful TPP, Thorstensen and Ferraz find that exports to this area would fall by $0,4 \%$ in the case of the dismantling of tariff barriers, and by $2,7 \%$ if tariff barriers and $50 \%$ of NTBs are eliminated. In a simulation which includes China in the TPP, the fall in Brazilian exports to this zone would amount to $1,4 \%$ due to tariff abolishment, and to $5 \%$ if a $50 \%$ NTB reduction is added to this. A general evaluation of the authors' findings thus points to the weight of NTBs, relative to tariff reductions. This suggests that exclusion from agreements that apply a strong focus on regulatory issues may lead to notable costs for Brazil, while the impacts from pure tariff reduction within freetrade zones are relatively negligible.

A noteworthy element in Thorstensen and Ferraz (2014) can be found in their projections of the economic implications of the conclusion of preferential trade agreements among Brazil and the US and EU 27, in scenarios of different degrees of tariff and NTB reduction, which are listed in Table 1 below: 
Table 1: Changes in Brazilian exports and imports with the EU 27 and the US in different scenarios of tariff and NTB reductions

\begin{tabular}{|l|c|c|}
\hline & $\begin{array}{c}\% \text { Increase } \\
\text { in Brazilian } \\
\text { exports }\end{array}$ & $\begin{array}{c}\% \text { Increase } \\
\text { in Brazilian } \\
\text { imports }\end{array}$ \\
\hline Tariff elimination with the EU 27 & $21,2 \%$ & $43,7 \%$ \\
\hline Tariff elimination with the US & $9,9 \%$ & $43,6 \%$ \\
\hline Tariff elimination with the EU $27+25 \%$ NTB reduction & $57,4 \%$ & $71,3 \%$ \\
\hline Tariff elimination with the US + 25\% NTB reduction & $47,6 \%$ & $75,9 \%$ \\
\hline Tariff elimination with the EU 27 + 50\% NTB reduction & $97,5 \%$ & $101 \%$ \\
\hline Tariff elimination with the US + 50\% NTB reduction & $93,5 \%$ & $112,4 \%$ \\
\hline
\end{tabular}

Source: Adaption from Thorstensen and Ferraz (2014).

Though very marked gains in terms of export increases can be registered, imports surge even more significantly in all of the scenarios listed, indicating the potential of trade balance deficits. Thus, without neglecting the possible welfare gains of closer integration into global commodity chains, the costs from non-participation should nevertheless be held up against the costs of participating in agreements in which the gains of competitive export-sectors may not surpass the losses incurred by less competitive domestic industries.

Brandão (2015) focuses his projections on the specific sectorial repercussions of tariff eliminations between the EU and the US. Though tariff reductions usually are seen as less important in mega-regionals when compared to regulatory changes, certain sector peaks - specifically within agriculture - do point to the relevance of examining how tariff phase-out between the US and the EU might affect Brazil. In a simulation of complete tariff elimination in all sectors between the US and EU, the indirect effect on Brazilian exports are fairly negligible, totaling a loss of some US\$ 169 million, while Brazil's imports decline by some US\$ 313 million. In a second simulation, all tariffs in all sectors are eliminated among the EU, the US, and Brazil. In this scenario, Brazilian exports of meat and sugar would surge by US\$ 17,7 billion and US\$ 4,5 billion, respectively, while exported manufactures would decline by US\$ 6,4 billion. Brazilian manufacture imports would rise by US\$ 16 billion and the total increase in imports of US\$22,9 billion would be considerably higher than the projected total rise in exports of US\$ 5,6 billion. Production of meat and sugar would thus augment by $38 \%$ and $24,4 \%$ respectively, which would be accompanied by a fall in domestic manufacturing of $6 \%$, and in soybean production of $8 \%$. In likeness with Thorstensen and Ferraz (2014), Brandão's results reveal that the immediate implications of commercial opening for Brazil could well be associated with a deterioration in the trade balance. The findings also draw attention towards the risk that increased commercial integration with the US and 
the EU might exacerbate Brazil's global insertion as a raw material exporter and push further in the direction of domestic de-industrialization.

Aichele et al., (2014) analyze the consequences of a TTIP conclusion for thirdcountries. The authors project the changes in trade flows between a range of signatories and third-countries, under the presumption that all transatlantic tariff barriers are eliminated, and that NTBs are reduced to an average level for existing PTAs. The study finds that the conclusion of TTIP would lead to a decline in Brazilian exports and value added transfers in the case of both member countries and third-parties, as is displayed in Table 2 below:

Table 2: Trade effects on Brazil of the conclusion of the TIPP

\begin{tabular}{|l|c|}
\hline & $\begin{array}{c}\text { \% Change in trade flows and value added } \\
\text { transfers for each country/block }\end{array}$ \\
\hline ASEAN & $-1 \%$ \\
\hline Canada & $-2 \%$ \\
\hline China & $-3 \%$ \\
\hline EU 27 & $-1 \%$ \\
\hline Mexico & $-3 \%$ \\
\hline Turkey & $1 \%$ \\
\hline US & $-7 \%$ \\
\hline
\end{tabular}

Source: Adaption from Aichele et al., (2014).

While Brazilian exports and value added transfers to the EU 27 remain unchanged, a moderate decline can be registered in the case of ASEAN and China, and a more significant fall becomes evident with regards to the US, Canada, and Mexico. This finding indicates that the TTIP's third-party impact on Brazil will be somewhat negative.

Yet, one of the central pillars of the TTIP relates to the ambition of reaching a high degree of regulatory convergence and harmonization. The study therefore contains simulations in which the premise of moderate NTB reductions is changed to significant standards harmonization. Due to the reduction of production costs for export sectors in third-countries, positive spillovers in terms of GDP increases are registered for the group of non-TTIP countries, ranging between 0,23-1,21\%. In this projection, Brazil appears within the Mercosul group, which accounts for a GDP increase between $0,18-0,84 \%$, depending on the extent of positive spillover effects from intra-TTIP harmonization. Thus, when the potential positive effects of regulatory harmonization spillovers are taken into account, it becomes more difficult to make a conclusive evaluation of whether the TTIP would affect Brazil negatively. So, in spite of painting a muddy picture of the particular consequences of standards harmonization within mega-regionals, in likeness with Thorstensen and Ferraz (2014), the projections of Aichele et al., do point to the undeniable 
significance of the complex effects associated with regulatory convergence, relative to traditional logics of exclusion/inclusion.

A study conducted by Felbermeyer et al., (2013) draws up a less dim scenario of the third-party impact on Brazil, associated with the signature of a transatlantic free-trade agreement in the moulds of the TTIP proposal. As these projections suggest a considerable welfare effect of tariff and/or NTB liberalizations between the EU and the US, they therefore also indicate that a few select raw material producers would stand to increase exports, and concomitantly also experience a positive impact on GDP. Noticeably, the study indicates that Brazil stands as one of the few developing countries to see indirect welfare gains from the TTIP: while the tariff reduction scenario results in a $0,5 \%$ increase in Brazilian GDP, the "deep liberalization" scenario - which implies a significant NTB reduction and investment facilitation element - results in a 2,1\% increase in Brazilian GDP. It should be noted that Felbermeyer et al., (2013) stands out in the category of economic impact studies, as its country-projections of either positive or negative GDP variations are much more highly estimated than those of other research projects within this area. In this regard, it is remarkable to observe how Brazil as an outsider is expected to grow up to $2,1 \%$ due mainly to increased raw material demand in member countries.

Cai et al., (2015) also conduct a projection of the third-country impact of a TTIP conclusion, implying tariff and non-tariff barrier reductions. The authors operate with the assumption that $20 \%$ of NTB reductions among member countries will spill over onto outsiders. The study finds that in the case of Brazil, these effects surpass losses due to trade diversion, leading to a $0,33 \%$ increase in aggregated Brazilian exports, and a $0,29 \%$ increase in aggregated imports. This is a accompanied by a $0,1 \%$ GDP increase. At a 2027 benchmark, exports to the US and EU are thus expected to increase by $4,7 \%$ and $1,6 \%$ due to positive spillovers of the TTIP. The authors find that trade substitution effects means that Brazil increases exports to all of the other BRICS countries, with $0,21 \%$ in the case of China, $0,16 \%$ for India, $0,77 \%$ for South Africa, and 1,07\% for Russia.

Fleishhaker et al., (2016) focus on assessing the likely impact of a handful of mega-regional agreement proposals on the Latin American countries. The study projects different scenarios of real income and sector-wise change departing from the conclusion of the TTIP, TPP, RCEP, and the Free Trade Area of the Asia-Pacific (FTAAP). The authors find that the TTIP, the TPP, and the RCEP, would leave Brazil as a third-party virtually unaffected in terms of GDP change, varying from $-0,1 \%$ in the former cases to $0 \%$ in the latter. In the case of the FTAAP - the agreement at the most incipient stage - a more significant effect of a 1,95\% increase in Brazilian GDP is found to be evident. Yet, these projections do suggest that flows and the composition of Brazil's exports would be significantly altered by the mega-regionals. Thus, while the TPP would lead to a $4,4 \%$ increase in exports to China, Fleishhaker et al., find that these would undergo a leap of $84 \%$ below the FTAAP due to surging Chinese commodity demand. European imports of Brazilian raw material inputs are also found to rise under the TTIP, which nonetheless is negatively compensated by declines in Brazilian exports to the US and China. The authors' findings 
also indicate that the value added effects of the mega-regionals only would be positive in the case of the Brazilian mining sector, while negative impacts are registered in the case of manufacturing. It is therefore highlighted that the indirect effects of the mega-regionals might well be to further lock Brazil into a role as a global primary commodity supplier.

Finally, Cerdeiro (2016) projects the impacts of the TPP on different Latin American and Caribbean countries through simulations of tariff liberalization, with or without NTB reductions. The third-party impact of tariff liberalization within the TPP area on Brazil as a non-participant are found not to affect Brazilian GDP, while full tariff liberalization and NTB reductions are estimated to lead to a drop in the lower end of $0,1 \%$ - leaving the Brazilian economy essentially unaffected. In simulations in which Brazil joins the TPP, a modest GDP increase of $0,18 \%$ is found in the tariff liberalization scenario, while the tariff + NTB scenario is associated with a $0,25 \%$ rise, indicating relatively modest gains derived from participation.

\section{STRUCTURAL IMPLICATIONS FOR BRAZIL}

From the projections reviewed, it becomes very difficult to draw any definitive conclusions with regards to the immediate consequences of Brazil standing outside the mega-regional agreements. Though some estimates indicate losses due to trade diversion, most tend to suggest that the positive spillover effects of regulatory harmonization and increased commodity demand either means that the Brazilian economy is unaffected, or even positively impacted. Yet, it should be noted that these studies mainly focus on yielding information about the measurable short- and intermediate term consequences for Brazil as a third-country. The possible global consolidation of mega-regional agreements would also wield a range of significant structural implications, characterized by greater complexity in terms of their detection, but with potentially deeper repercussions.

It therefore becomes interesting to observe how some of the studies reviewed suggest an increased participation of primary commodities within the structure of Brazilian exports, both in scenarios in which Brazil joins, or stand outside different proposed mega-regional agreements. These findings should thereby feed into recently expressed worries of gradual de-industrialization (Dávila-Fernándesz, 2015) symptoms of commodity-induced Dutch disease (Bresser-Pereira et al., 2016; Bacha \& Fishlow, 2011) as well as the relatively declining significance constituted by manufactures and high technology inputs within Brazilian exports (Cunha et al., 2013; Pereira \& Dathein, 2016), and the challenges of tapping into global value chains (Hiratuka \& Arti, 2017). Crossing such considerations with the findings of the projections reviewed might support the core argument in Rodrik et al., (2004), who underline how the enhancement of economic performance rests on improvement of domestic productive institutions, rather than on increasing openness to international trade per-se, which in the absence of the first condition even might lead to a negative effect on welfare (Rodrik et al., 2004). 
A no less important issue regards how the rise of mega-regionals might position Brazil in relation to the emerging sites of rule-making for a substantial part of global economic interaction. Independently of the eventual obstacles for their near future materialization, the rising wave of prefenrentialism within the global trade order, of which the mega-regionals are part, is held by Winters as inherently asymmetrical, and as a preoccupying threat to multilateralism (Winters, 2015). A very contrary perception can be detected in Mercurio, who welcomes the mega-regionals as a possibility for the US to circumvent developing countries such as Brazil, India, and China by proliferating its preferred standards and norms, which subsequently can be "multilateralized" through the WTO, when they already have become globally prevalent (Mercurio, 2014).

The possibility that the conclusion of the TTIP would subordinate the WTO to a secondary status is also emphasized by Silva, meaning that this organization would be reduced to implementation of rules agreed upon between a range of select parties (Silva, 2014, p.394). This raises the question of whether the mega-regionals actually fall within Keohane and Morse's (2014) category of "contested multilateralism" as alternative institutional vehicles of establishing rules outside the multilateral track. Though the varying degree of exclusivity of these negotiations might conflict with the authors' definition of this trend as "multilateral responses", the general account of coalitions contesting the status quo "when change in existing multilateral institutions is difficult" does hold some similarities with the background for the proliferation of mega-regional negotiations (Keohane \& Morse, 2014, p.386-387).

There appears to be clear consensus within IPE literature, that the broader political and economic significance of who makes the rules for global commercial interaction is far from trivial. Eliasson and García-Duran thus stress the character of the TTIP as a "geopolitical game-changer" as it would constitute a mechanism of "regulatory export", in accordance with which third-countries would have had to adapt (Eliasson \& García-Duran, 2016). The costs which particularly developing countries may incur as they conform to developed-country standards are strongly emphasized by Maur and Shepherd, who also stress how this might not result in a "socially optimal level of regulation" for these states (Maur \& Shepherd 2011, p.197). In a similar vein, Falk and Unmusig maintain that even though developing countries might join the mega-regionals, most of them would adopt pre-defined standards "through the back door" and would not gain status as "rule setters" (Falk \& Unmusig, 2014). Baldwin also associates the conclusion of the TTIP of the TPP with the inevitability that Chinese, Indian, or Brazilian enterprises eventually would have to abide by developed country standards. Though Baldwin does point to some potentially positive implications of such an internalization, he nonetheless also stresses how this might entail certain undesirable restrictions for producers in these countries (Baldwin, 2014b).

When evaluating mega-regional trade agreements' character as a norm-setting project of power projection, the temporal context in which they are devised also appears to become relevant. De Bievre and Poletti (2014) pinpoint how the erosion 
of the EU's bargaining power became evident during the Doha Round, which from the late 2000s pushed the Union away from multilateralism and towards engagement in PTA negotiations (De Bievre \& Poletti, 2014, p.33). In line with Gantz and Nielsen (2016), the North Atlantic economic superpowers presently have a historical opportunity to shape the rules of the global trading system, which in a few decades will be bygone with the increasing influence of developing countries such as China, India, and Brazil (Gantz \& Nielsen, 2016). Carneiro also paints a bleak picture of the possible consolidation of mega-regionals in relation to Brazil, which effectively would be excluded from the governance of world trade (Carneiro, 2014). As the commercial participation of developing countries becomes ever more accentuated globally (Dadush, 2015), as well as in the Brazilian import-export composition (Farias, 2015, p.8), the question remains as to whether the present halt of the mega-regionals, and their possible postponement at least towards the early 2020s, might in fact have been generally beneficial for developing countries - and in particular for Brazil?

\section{CONCLUSIVE SUMMARY}

The revision of literature treating the transformations of the global trading system, away from multilateralism and towards preferentialism, points to the increasing importance of regulatory convergence and other non-tariff related issues. In spite of the significant obstacles prohibiting their ratification or final conclusion, the mega-regional trade agreements examined stand as a present culmination of the concretization of these trends. The projections of their impact on Brazil as a third-party may thus help to shed light on how these underlying dynamics of legal/ regulatory streamlining shape the future premises for Brazilian participation within international commerce. The present examination of studies within the area has been structured in order to differentiate assessments of short-term and long-term effects. Revisions of projections of the short-term economic impacts on Brazil provide very mixed conclusions, mainly ranging from negligible to slightly positive. These studies also indicate that participation could mean that Brazil lost out in value added sectors, while its position as a raw material provider would be cemented, and also point to serious trade balance issues. The long-term implications of the mega-regionals are strongly related to participation in the establishment of rules for world trade. The reviews indicate that in their present format, mega-regional proposals have been strongly defined by the US and the EU. Thus, if the agreements had materialized, these rule-sets would either be directly imposed on Brazil if it sought posterior integration within the mega-regionals - as through the EU-Mercosul negotiations - or indirectly, in the case of Brazilian non-participation, as they would shape the normative foundation for global trade. Contrary to arguments postulating the need for Brazilian participation, the present review article indicates that for now, these agreements' non-materialization may be indeed be rather preferable to the second largest economy of the Americas. 


\section{REFERENCES}

Acharya, Rohini; Crawford, Jo-Ann; Maliszewska, Maryla; Renard, Christelle (2011) Landscape in Chauffour, Jean-Pierre; Maur, Jean-Christopher (eds.) Preferential Trade Agreement Policies for Development, The World Bank: 37-68.

Aggarwal, Vinod K.; Evenett, Simon J. (2015) "Must TTIP-induced regulatory convergence benefit others?" in Akman, M. Sait, Evenett, Simon J. and Low, Patrick (eds.) Catalyst? TTIP's impact on the Rest. CEPR Press: 43-50.

Aichele Rahel; Felbermayr Gabriel; Heiland Inga (2014) “Going Deep: The Trade and Welfare Effects of TTIP”. CESIFO Working Paper n. 5150.

Aichele, Rahel; Felbermayr, Gabriel. (2015) The Trans-Pacific Partnership Deal (TPP): What Are the Economic Consequences for In- and Outsiders? CESifo Forum 4: 53-64.

Akman, M. Sait; Evenett Simon J.; Low, Patrick (2015) Introduction_in Akman, M. Sait, Evenett, Simon J. and Low, Patrick (eds.) Catalyst? TTIP's impact on the Rest. CEPR Press: 1-10.

Alan, L. Winters (2015) "The WTO and Regional Trading Agreements: Is it all over for Multilateralism?” EUI Working Papers, Robert Schuman Centre for Advanced Studies Global Governance Programme.

Anuradha, R.V. (2016) "Rise of the Plurilaterals: Threat or Opportunity for Multilateral Trade Governance" in Chaisse, Julien; Tsai-Yu, Lin (eds). International economic law economic law and governance essays in honor of Mitsuo Matsushita: 411-426. Oxford: Oxford University Press.

Bacha Edmar L.; Fishlow, Albert (2011) "The Recent Commodity Price Boom and Latin American Growth: More than New Bottles for an Old Wine?” In Ocampo, José Antonio; Ros, Jaime (eds.) The Oxford Handbook of Latin American Economics. Oxford Handbooks Online: 1-21.

Baldwin, Richard (2014a) “The Economic Impact in González, Anabel (ed.) Mega-regional Trade Agreements Game-Changers or Costly Distractions for the World Trading System?"WEF Papers: 2224.

Baldwin, Richard (2014b) The Systemic Impact in González, Anabel (ed.) Mega-regional Trade Agreements Game-Changers or Costly Distractions for the World Trading System? WEF Papers: 25-28.

Bernal-Meza, Raúl. (2008) "Argentina y Brasil en la Política Internacional: regionalismo y Mercosur (estrategias, cooperación y factores de tensión)”. Revista Brasileira de Política Internacional 51 (2): 154-178.

Bhagwati, Jagdish (2008) Termites in the Trading System: How Preferential Agreements Undermine Free Trade. Oxford University Press Scholarship Online.

Bown. Chad, P. (2017) "Mega-Regional Trade Agreements and the Future of the WTO". Global Policy 8(1): 107-112.

Braga, Carlos A. Primo (2015) “TTIP and Brazil: Much ado about nothing?” In Akman, M. Sait, Evenett, Simon J. and Low, Patrick (eds.) Catalyst? TTIP's impact on the Rest. CEPR Press: 75-82.

Brandão, Salazar P. (2015) "Free-trade area United States of America/European Union Impacts on Brazil”. Revista de Política Agrícola, 3:22-31.

Bresser-Pereira, Luiz Carlos; Nassif, André; Feijó, Carmem. (2016) “A Reconstrução da Indústria Brasileira: A Conexão entre o Regime Macroeconômico e a Política Industrial”. FGV Texto para Discussão 413.

Bull, Reeve, T.; Mahboubi, Neysun. A.; Stewart, Richard, B.; Wiener, Jonathan, B. (2015). “New Approaches to International Regulatory Cooperation: The Challenge of TTIP, TPP, and Mega-Regional Trade Agreements". Law and Contemporary Problems 78(1): 1-29.

Cai, Songfeng; Zhang, Yaxiong; Meng, Bo. (2015) "Spillover of TTIP on BRICS economies: a dynamic GVC-based CGE model". IDE Discussion paper n.485.

Canuto, Otaviano. (2015) Are mega-trade agreements a threat to Brazil? Let's talk development. The World Bank. 26/2/2015 Available from: http://blogs.worldbank.org/developmenttalk/ Access: $6 / 6 / 2015$

Carneiro, Flávio. L. (2014) "A Parceria Transpacífica: principais características e impactos sobre a regulação do comércio mundial”. Boletim de Economia e Política Internacional18: 59-72. 
Cerdeiro, Diego. A. (2016) "Estimating the Effects of the Trans-Pacific Partnership (TPP) on Latin America and the Caribbean (LAC)". IMF Working Paper 16/101.

Chen, Xiaoyang, M.; Mattoo, Aaditya. (2008) "Regionalism in standards: good or bad for trade?" Canadian Journal of Economics 41(3): 838-863.

Ciuriak, Dan. (2014) Mega Regionals and the Developing Countries. Trade Workshop held under the auspices of the Center for Global Development and the International Institute for Sustainable Development, Washington, D.C., 24 June 2014

Cunha, André, M; Lelis, Marcos. C.T; Fligenspan, Flávio, B. "Desindustrialização e comércio exterior: evidências recentes para o Brasil". Revista de Economia Politica, 33 (3): 463-485.

Dadush, Uri. (2014) "Potential Responses to Mega-regionals by Excluded Countries" in González, Anabel (ed.) Mega-regional Trade Agreements Game-Changers or Costly Distractions for the World Trading System? WEF Papers: 28-30.

Dadush, Uri. (2015) "Developments in the global economy and trading system effects: the transformation of world trade". in Dadush, Uri \& Osakwe, Chiedu (eds.) WTO Accessions and Trade Multilateralism Case Studies and Lessons from the WTO at Twenty: 25-51.Cambridge University Press.

Dávila-Fernández, Marwil, J. (2015) "Desindustrialização e o investimento em infraestrutura como instrumento conciliador de uma política industrial base no Brasil". Revista de Economia Política, 35(3):576-600.

De Bievre, Dirk; Falkner, (2014) “The EU in trade policy: from regime shaper to status quo power”. In Gerda \& Muller, Patrick (eds.) EU Policies in a Global Perspective: Shaping or Taking International Regimes. Oxon: Routledge.

De Bievre, Dirk; Poletti, Arlo (2016) "Why the Transatlantic Trade and Investment Partnership is not (so) new, and why it is also not (so) bad", Journal of European Public Policy: 1-16.

De Ville, Ferdi. (2016) “Regulatory Cooperation in TTIP. A risk for democratic policy making?” FEPS Policy Brief.

Elliott, Kimberley, Ann. (2016) “Mega-regional trade agreements: a threat for developing countries and the WTO?” Global View, Forum Issue 1: 10-11.

Eliasson, Johan, L.; García-Duran, Patricia (2016) "Why TTIP is an unprecedented geopolitical gamechanger, but not a Polanyian moment”. Journal of European Public Policy: 1-12.

Falk, Reiner; Unmusig, Barbara (2014) The great revenge of the North? TTIP and the rest of the world. March 10, 2014. Heinrich Boll Stiftung. https://www.boell.de/ Accessed: 6/6/2017

Farias, Rogério, S. (2015) Algo de velho, algo de novo: a Organização Mundial do Comércio, o Brasil e as transformações do sistema multilateral de comércio. Boletim Meridiano 47 16(151): 3-17.

Felbermayr, Gabriel; Heid, Benedikt; Lehwald, Sybille (2013) Transatlantic Trade and Investment Partnership (TTIP) Who benefits from a free trade deal? GED, Bertelmanns Stiftung.

Fleischhaker, Cornelius; George, Samuel; Felbermayr, Gabriel; Rahel Aichele (2016) A Chian-reaction? Effects of mega-trade agreements on Latin America. GED Study, Bertelmanns Stiftung.

Francois, Joseph; Manchin, Miriam, Norberg, Hanna; Pindyuk; Olga; Tomberger Patrick (2013) Reducing Transatlantic Barriers to Trade and Investment: An Economic Assessment. Centre for Economic Policy Research.

Freytag, Andreas; Draper, Peter; Susanne, Fricke (2014) The impacts of TTIP. Konrad Adenauer Stiftung.

Gantz, David, A.; Nielsen, Laura (2016) TTIP and the Post- Bali WTO: Towards a New World Trade Order? in Chaisse, Julien; Tsai-Yu, Lin (eds). International economic law economic law and governance essays in honor of Mitsuo Matsushita: 367-391. Oxford: Oxford University Press.

Gil, Manrique, M.; Lerch, Marika; Bierbrauer, Elfriede. (2015) The TTIP's potential impact on developing countries: A review of existing literature and selected issues. EU Directorate General for External Policies: 4-24.

Hamilton, Daniel; Blockmans, Steven (2015) The Geostrategic Implications of TTIP CEPS Special Report n.105. ISBN 978-94-6138-459-1. 
Herwig, Alexia. (2016) TTIP Regulatory Cooperation: Changes in Transnational Risk Regulation from WTO Law and WTO Consistency. Symposium on TTIP Leaks. EJRR: 262-268.

Hiratuka, Célio; Sarti, Fernando. (2017) “Transformações na estrutura produtiva global, desindustrialização e desenvolvimento industrial no Brasil”. Revista de Economia Política, 37(1)189-207.

Hoekman, Bernard, M. (2015) "The WTO and the global economy: contemporary challenges and possible responses". In Dadush, Uri \& Osakwe, Chiedu (eds.) WTO Accessions and Trade Multilateralism Case Studies and Lessons from the WTO at Twenty: 52-80. Cambridge University Press.

Illescas, Nelson. (2015) O Mercosul e os acordos mega regionais: os custos para os que estão de fora. October 19, 2015, International Centre for Trade and Sustainable Development. Available from: http://www.ictsd.org/bridges-news/pontes/news Access 6/6/2017.

Josling, Tim (2011) “Agriculture”. In Chauffour, Jean-Pierre; Maur, Jean-Christopher (eds.) Preferential Trade Agreement Policies for Development, The World Bank: 143-160.

Keohane, Robert, O; Morse, Julia, C. (2014) “Contested Multilateralism”. Rev Int. Organ. 9:385-412.

Low, Patrick (2015) “TTIP and the world trading system". In Akman, M. Sait, Evenett, Simon J. and Low, Patrick (eds.) Catalyst? TTIP's impact on the Rest. CEPR Press: 13-18.

Maur, Jean-Christophe; Shepherd, Ben (2011) "Product Standards" in Chauffour, Jean-Pierre; Maur, Jean-Christopher (eds.) Preferential Trade Agreement Policies for Development, The World Bank: 197-216.

Maskus, Keith E; Otsuki, Tsunehiro; Wilson, John. S. (2005) The Cost of Compliance with Product Standards for Firms in Developing Countries: An Econometric Study. World Bank Policy Research Working Paper 3590.

Mattoo, Aaditya (2015) "An EU-US trade deal: Good or bad for the rest ofthe world?"/ In Akman, M. Sait, Evenett, Simon J. and Low, Patrick (eds.) Catalyst? TTIP's impact on the Rest. CEPR Press: $35-42$.

Mavroidis, Petros, C. (2011) "Always look at the bright side of non-delivery: WTO and Preferential Trade Agreements, yesterday and today”. World Trade Review 10 (3): 375-387.

Meléndez-Ortiz, Ricardo (2014) “Mega-regionals: What Is Going on?”.In González, Anabel (ed.) Mega-regional Trade Agreements Game-Changers or Costly Distractions for the World Trading System? WEF Papers: 13.

Mendoza, Miguel Rodríguez (2012)"Free-trade agreements in South America. Trends, prospects and challenges" Public Policy and Productive Transformation Series n. 7.

Menon, Jayat. (2014) "From Spaghetti Bowl to Jigsaw Puzzle? Fixing the Mess in Regional and Global Trade". Asia \& the Pacific Policy Studies 1(3): 470-483.

Mercurio, Bryan. (2014) “The Trans-Pacific Partnership: Suddenly a'Game Changer”. The World Economy: $1558-1574$.

Nakagawa, Junji (2016) "Regulatory Co-operation and Regulatory Coherence through Mega- FTAs: Possibilities and Challenges". In Chaisse, Julien; Tsai-Yu, Lin (eds). International economic law economic law and governance essays in honor of Mitsuo Matsushita: 392-426. Oxford: Oxford University Press.

Schmieg, Evita. (2015) “TTIP - Opportunities and Risks for Developing Countries”.SWP-Zeitschriftenschan 1 e: $1-8$.

Pereira, Lia Valls. (2013) “A “nova onda de regionalismo”: uma reflexão sobre a agenda brasileira.” Mural Internacional, ano IV (1): 2-7.

Pereira, Adriano, J; Dathein, Ricardo (2016) "The role of transnational corporations in the international insertion of Brazilian manufactures in the context of productive restructuring". Brazilian Journal of Political Economy, 36(4): 769-787.

Rodrik, D.; Subramanian, A.; Trebbi, F. (2004) “Institutions Rule: The Primacy of Institutions Over Geography and Integration in Economic Development". Journal of Economic Growth 9:131165.

Schroeder, Werner. (2016) “Transatlantic Free-trade agreements and European Food Standards”. European Food and Feed Law Review 6: 494-501. 
Schwab, Susan; Bhatia, Karan (2014) “Why Mega-regionals?” in Mega-regional Trade Agreements Game-Changers or Costly Distractions for the World Trading System? WEF Papers: 18-19.

Shedherd, Ben. (2007) Product Standards, Harmonization, and Trade: Evidence from the Extensive Margin. World Bank Development Research Group.

Silva, A.R. (2014) “O redimensionamento da OMC no trato dos Acordos Comerciais Regionais". Revista de Direito Internacional 12(2): 387-401.

Solís, Mireya; Wilson Jeffrey D. (2017) "From APEC to mega-regionals: the evolution of the Asia-Pacific trade architecture. The Pacific Review: 1-15.

Sorgho, Zakaria (2016) "RTAs' Proliferation and Trade-diversion Effects: Evidence of the 'Spaghetti Bowl' Phenomenon". The World Economy: 285-300.

Thorstensen, Vera. (2012) "Impactos da crise econômica e financeira na regulação do comércio internacional”. Boletim de Economia e Política Internacional: 33-43.

Thorstensen, Vera; Ferraz, Lucas. (2014) "O isolamento do Brasil em relação aos acordos e mega-acordos comerciais”. Boletim de Economia e Política Internacional, 16: 5-17.

Torezani, Tomás Amaral. (2016) "Possíveis repercussões dos mega-acordos comerciais nas exportações brasileiras". Panorama Internacional1(4).

Ulgen, Sinan. (2014) Locked in or left out: Transatlantic Trade Beyond Brussels and Washington. Carnagie Europe.

Viner, Jacob. (1950) The Customs Union Issue. Oxford University Press.

Wilson, Jeffrey, D. (2015) "Mega-Regional Trade Deals in the Asia-Pacific: Choosing Between the TPP and RCEP?" Journal of Contemporary Asia46(2): 345-353.

Yong, Wang (2014) “The Political Economy of the Mega-regionals” in González, Anabel (ed.) Mega-regional Trade Agreements Game-Changers or Costly Distractions for the World Trading System? WEF Papers: 20-21.

Young, Alasdair, R. (2015) "Liberalizing trade, not exporting rules: the limits to regulatory co-ordination in the EU's 'new generation' preferential trade agreements". Journal of European Public Policy:1253-1275.

Young, Alasdair, R. (2016) “Not your parents' trade politics: The Transatlantic Trade and Investment Partnership negotiations”. Review of International Political Economy, 23(3): 345-378. 